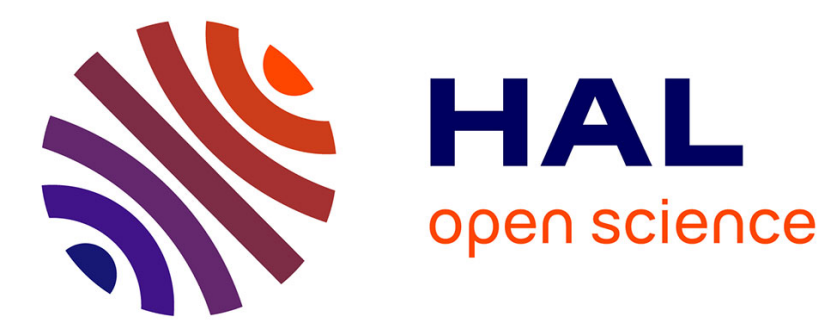

\title{
How to Talk about Media You Haven't Understood
}

Antonio A. Casilli

\section{To cite this version:}

Antonio A. Casilli. How to Talk about Media You Haven't Understood. Journal of Visual Culture, 2014, 13 (1), pp.26-28. 10.1470412913509445 . halshs-01055785

\section{HAL Id: halshs-01055785 https://shs.hal.science/halshs-01055785}

Submitted on 17 Aug 2014

HAL is a multi-disciplinary open access archive for the deposit and dissemination of scientific research documents, whether they are published or not. The documents may come from teaching and research institutions in France or abroad, or from public or private research centers.
L'archive ouverte pluridisciplinaire HAL, est destinée au dépôt et à la diffusion de documents scientifiques de niveau recherche, publiés ou non, émanant des établissements d'enseignement et de recherche français ou étrangers, des laboratoires publics ou privés. 
Antonio A. Casilli (2014) "How to Talk about Media You Haven't Understood". Journal of Visual Culture, special themed issue - "Marshall McLuhan's Understanding Media at 50", vol. 13, n. 1, pp. 26-28. doi: $10.1177 / 1470412913509445$

\section{How to talk about media you haven't understood}

In his essay How to Talk About Books You Haven't Read, French literary critic Pierre Bayard insists that the act of reading is not essential to the appreciation of the essence of a book - as long as we know how to position it in the broader ecosystem of a literary genre or of a field of knowledge. Following Oscar Wilde's tongue-in-cheek advice never to read a text one must review ('it prejudices you so...'), Bayard advocates the right to non-reading, in order to stimulate our creative imagination.

I, for one, have been sticking to this principle for most of my adult life. I've put off reading certain books as much as possible, while in the meantime avidly studying germane texts, secondary sources, and critical appraisals, so to have a comprehensive panorama of the literary environment of their authors. Moreover, this procrastination allows me to fantasize about their opinions, their style, their concealed intentions. I call this 'beating around the book.'

McLuhan's Understanding Media is no exception. For years I've been leafing through excerpts and commentaries - never the real thing. And to this day I wouldn't even have opened it, were it not for my students. When I started teaching classes on (new) media studies, the 1964 classic was on every list of compulsory readings. Reluctantly, I had to put my hands on a copy, too. It was the mid-noughties and the emphasis was on 'social' and participatory media. That largely shaped my expectations as to the content of the book. 
That also determined my initial disappointment as to what I deemed was missing in McLuhan's work. There I had an author who clearly drew inspiration from Harold Innis, who considered technologies as tools mediating processes of diffusion of cultural forms across spatial and time biases, and yet showed little awareness of the part played by human intermediaries in the transmission of messages across geographic, social and demographic boundaries. While his contemporaries Elihu Katz and Paul F. Lazarsfeld where already reflecting on how media contents moved across social networks via opinion leaders, brokers, and mediators, McLuhan didn't seem to take into account that part of the equation. His manifold influences included Edward T. Hall, Ralph Waldo Emerson, Pierre Teilhard de Chardin, none of whom (except maybe the last one) qualifies as an early pioneer of 'social' and 'new' media studies.

In a way it was like McLuhan's work left the role of social ties as structuring forces of diffusion untackled. From this point of view, situating Understanding Media in the larger field of communication and social sciences revealed more arduous than I thought. Yet, this realization coincided with the moment when my initial disappointment turned into genuine interest. I was intrigued by the fact this work exposed a schism between a holistic stance, descriptive and focusing on the content of mediatic communication, and a more empirically-driven one, micro- and mesosociologically-oriented, sensitive to the context of the mediated communication. For the former, McLuhan's catchphrase 'The medium is the message' was valid. For the latter, it was also valid but - in an admittedly less incisive phrasing - it read: 'The medium is the structure of the social network describing the ties between the social agents uttering the message.'

No incident summarizes the tension between these two approaches better than the 1955 Columbia University Teacher's College seminar clash that opposed the then- 
budding Canadian information theorist and the dean of US sociology, Robert K. Merton. The anecdote is related in Paul Levinson's Digital McLuhan, one of the germane books I engaged with while postponing reading Understanding Media:

[Merton stood up] purpled with outrage and proceeded to say: 'Just about everything in your paper requires cross-examination!' He started with the first paragraph, sonorously ticking off all the points in want of further explanation, a William Jennings Bryan making a closing argument to the jury about why the accused should be found guilty of murdering the scholarly procedure. (Levinson, 1999:24)

Retrospectively, I cannot help thinking that Merton was somehow set against McLuhan by Lazarsfeld with whom, one year before, he had co-written Friendship as a Social Process, the text establishing the notion of homophily as the individual propensity to communicate and create preferential ties with persons displaying shared characteristics. For decades, their seminal contribution would remain relatively unknown outside a restricted circle of English-speaking academics, while McLuhan would go on to meet international success with Understanding Media.

Here another type of schism comes to light, this time in terms of timing and public reception. If up to the 1990s McLuhan's analysis were considered indispensable to figure out how 'mass' media worked, in the 2000s Merton and Lazarsfeld's approach got the upper hand, as far as their approach turned out to be crucial to our grasp of how 'social' media function. Today's interminable debates about online 'echo chambers', or the emphasis on the nature and effects of computer-mediated 'friendships', seem to respond to the theoretical framework established by the context-aware stance embodied by the two sociologists. Homophily in Internet social 
networks stands as a prominent theoretical concern for scholars researching webbased political phenomena, cultural consumption, or relationship building.

Yet this relative cyclicality betrays the fact that the two approaches are complementary, rather than opposed. The focus on content and the one on context go together-they alternate, interchange, the one lives in the negative space left by the decline of the other. Which is why today's McLuhan's voice still has something to say to our understanding of contemporary media. Even if, in fact, he did not understand them.

\section{REFERENCES}

Bayard, P (2007) How to talk about books you haven't read. New York, NY:

Bloomsbury.

Lazarsfeld, P. F. \& R. K. Merton (1954) Friendship as a Social Process: A

Substantive and Methodological Analysis. In: M. Berger, T. Abel, and C. H. Page

(eds) Freedom and Control in Modern Society. New York: Van Nostrand: 18-66.

Levinson, P (1999) Digital McLuhan: A Guide to the Information Millennium.

London: Routledge.

Antonio A. Casilli

Economics \& Social Sciences Department Telecom ParisTech (Ecole Nationale Supérieure des Télécommunications) EHESS (Ecole des Hautes Etudes en Sciences Sociales), Paris. 